\title{
KEEFEKTIFAN MODEL PEMBELAJARAN KOOPERATIF TIPE BAMBOO DANCING DALAM KETERAMPILAN BERBICARA BAHASA JERMAN SISWA KELAS XI IPA SMA NEGERI 7 BULUKUMBA
}

\author{
Harianto $^{1}$ dan Ambo Dalle ${ }^{2}$ \\ Program Studi Pendidikan Bahasa Jerman \\ Fakultas Bahasa dan Sastra Universitas Negeri Makassar \\ Email: harianto.anton96@gmail.com ${ }^{1}$
}

\begin{abstract}
ABSTRAK
Tujuan Penelitian ini adalahuntuk memperoleh data dan informasi mengenai keefektifan model pembelajaran kooperatif tipe bamboo dancing dalam keterampilan berbicara bahasa Jerman siswa kelas XI IPA SMA Negeri 7 Bulukumba. Penelitian ini merupakan jenis quasi experiment. Pengumpulan datanya melalui tes keterampilan berbicara. Data dianalisis dengan uji-t. Populasi penelitian ini yaitu seluruh siswa kelas XI IPA SMA Negeri 7Bulukumba yang terdiri dari 4 kelas berjumlah 102 siswa. Teknik Sampel yang digunakan adalah Random Sampling. Jumlah sampel adalah 50 siswa. XI IPA 1 sebagai kelas eksperimen berjumlah 24 siswa dan XI IPA 3 sebagai kelas kontrol berjumlah 26 siswa. Hasil analisis data menggunakana uji-t menunjukkan bahwa $\mathrm{t}$-hitung $(3,85)>\mathrm{t}_{\text {-tabel }} 2,011$ pada taraf signifikan $\alpha=$ 0,05. Hasil penelitian menunjukkan bahwa model pembelajaran tipeBamboo Dancing efektif dalam pembelajaran keterampilan berbicara bahasa Jerman siswa kelas XI IPA SMA Negeri 7 Bulukumba.
\end{abstract}

Kata Kunci: Bamboo Dancing, Keterampilan Berbicara, Bahasa Jerman.

\section{ASBTRACT}

The purpose of this research is to obtain data and information about the effectiveness of cooperative learning model of bamboo dancing type in German speaking skill. This research is a kind of quasi experiment. Data collection through speech test. Data were analyzed by ttest. The population of this study is all students of class XI IPA SMA Negeri 7 Bulukumba consisting of 4 classes amounted to 102 students. Sample technique used is Random Sampling. The sample size is 50 students. XI IPA 1 as the experiment class is 24 students and XI IPA 3 as the control class is 26 students. The result of data analysis using t-test shows that $\mathrm{t}$-count $(3,85)>\mathrm{t}$-table2,011 at significant level $\alpha=0,05$. The result of the research shows that the learning model of Bamboo Dancing type is effective in learning German language speaking skill.

Keywords: Bamboo Dancing, Speaking Skill, German language. 


\section{PENDAHULUAN}

Bahasa merupakan salah satu bagian dalam kebudayaan yang ada pada masyarakat. Bahasa terdiri atas bahasa lisan dan tulisan. Sebagai bagian dari kebudayaan di mana manusia memegang peranan penting, bahasa juga turut ambil bagian dalam peran manusia itu karena fungsinya sebagai alat komunikasi yang terus berkembang sesuai dengan perkembangan peradaban manusia (Romadloni dkk, 2017). Oleh karena itu, seseorang diharapkan bukan hanya dapat menguasai bahasa nasionalnya, namun juga perlu menguasai bahasa asing. Tanpa penguasaan bahasa asing yang baik, tidak akan ada kerjasama yang baik antarnegara. Hal tersebut menjadi alasan Depdiknas 2006 mulai menerapkan bahasa asing melalui dunia pendidikan seperti bahasa Inggris, bahasa Jerman, bahasa Mandarin, bahasa Prancis, bahasa Jepang, dan bahasa Arab sebagai mata pelajaran, baik mata pelajaran wajib ataupun mata pelajaran muatan lokal.

Salah satu bahasa asing yang juga sangat berpengaruh di dunia adalah bahasa

Jerman. Bahasa Jerman merupakan salah satu bahasa asing terpenting kedua di benua Eropa setelah bahasa Inggris dan menempatkan bahasa Jerman diurutan ke 3 terpopuler di dunia. Bahasa Jerman memegang peranan penting dalam mengembangkan ilmu pengetahuan dan juga dunia pendidikan. Dengan penguasaan bahasa Jerman yang baik, maka akan berpeluang untuk mendapatkan pendidikan di Indonesia dan Jerman. Selain itu terdapat banyak perusahaan dari Jerman di Indonesia yang memberikan peluang untuk mendapatkan pekerjaan.
Terdapat empat kompetensi berbahasa dalam pembelajaran bahasaJerman yang diajarkan, diantaranya mendengar (Hören), berbicara (Sprechen), membaca (Lesen), menulis (Schreiben), dan serta ditunjang dua aspek kemampuan, yaitu tata bahasa (Strukturen) dan kosakata (Wortschatz). Dari keempat kompetensi berbahasa tersebut, keterampilan berbicara berperan penting dalam pengajaran bahasa. Dikatakan penting, karena melalui kegiatan berbicara, seseorang dapat menyampaikan informasi maupun pengetahuan dalam berbagai disiplin ilmu.

Menyadari betapa pentingnya kegiatan berbicara, kebiasaan berbicara, dan dasar kemampuan berbicara, maka perlu ditanamkan kepada siswa sedini mungkin. Hal ini akan tercapai apabila bimbingan berbicara dalam pengajaran bahasa Jerman di sekolah-sekolah diberikan secara sistematis dan terus menerus oleh pendidik. Untuk dapat berbicara dalam bahasa Jerman, siswa harus mampu melafalkan kata atau kalimat dalam bahasa Jerman. Akan tetapi, siswa seringkali bingung dan takut salah ketika melafalkan kata atau kalimat dalam bahasa Jerman. Hal itu terjadi karena banyaknya cara pelafalan yang diajarkan oleh pendidik yang seringkali berbeda serta kurangnya strategi yang baik dari pendidik dengan hanya mengandalkan teori ceramah atau diskusi. Dengan demikian, kemampuan berbicara menjadi terkendala dan berdampak pada konsep yang sering menyimpang dari tujuan pokok materi dan pengetahuan siswa terhadap materi. Namun hal ini tidak dapat dihindari karena berbicara adalah tuntutan dari sebuah bahasa yang wajib dilaksanakan.

Salah satu model pembelajaran yang dapat membantu untuk meningkatkan 
keterampilan berbicara siswa adalah melalui model pembelajaran kooperatif. Pada pembelajaran kooperatif atau cooperative learning siswa diberikan kesempatan untuk meningkatkan kemampuannya secara aktif dalam kelompok belajarnya sehingga terjadi ketergantungan positif dalam pemahaman materi (Mantasiah dkk, 2017; Yusri dkk, 2018; Qalbi, 2017).

Pada dasarnya pembelajaran kooperatif mengandung pengertian sebagai suatu sikap atau perilaku bersama dalam bekerja atau membantu diantara sesama dalam struktur kerjasama yang teratur dalam kelompok, yang terdiri dari dua orang atau lebih dimana keberhasilan kerja sangat dipengaruhi oleh keterlibatan dari setiap anggota kelompok itu sendiri (Jufri, 2007; Jufri, 2017). Ada beberapa strategi dalam pembelajaran kooperatif yang dapat diterapkan pada keterampilan berbicara. Salah satunya adalah tipe Bamboo Dancing.

Model pembelajaran Bamboo Dancing atau tari bambu merupakan pembelajaran yang memberikan kesempatan siswa untuk saling berbagi informasi pada saat yang bersamaan dengan pasangan yang berbeda dalam waktu singkat secara teratur strategi ini tepat untuk materi yang membutuhkan pertukaran pengalaman pikiran dan informasi antarsiswa. Meskipun namanya tari bambu, tetapi tidak menggunakan bambu. Siswa yang berjajarlah yang diibaratkan sebagai bambu.

Berdasarkan hasil observasi yang telah dilakukan di SMA Negeri 7 Bulukumba dan wawancara dengan guru mata pelajaran bahasa Jerman menunjukkan bahwa keterampilan berbicara siswa masih rendah dan kurang dikembangkan secara optimal dalam pembelajaran. Hal ini digambarkan dari kurangnya antusias siswa dalam mengikuti pembelajaran bahasa Jerman khususnya keterampilan berbicara.

Penelitian ini diperkuat oleh beberapa hasil penelitian berbagai metode dan model pembelajaran yang telah diterapkan dalam pembelajaran berbicara diantaranya penelitian yang telah dilakukan olehTahang (2013:95) menunjukkan bahwa keterampilan berbicara bahasa Jerman siswa kelas XI IPA 1 SMA Negeri Pinrang termasuk dalam kategori sedang dengan hasil $(87,5 \%)$. Adapun penelitian dari Juwita (2015:48), hasil penelitian tersebut mengungkapkan bahwa keterampilan berbicara bahasa Jerman siswa kelas XI IPA SMAN 11 Makassar termasuk dalam kategori sedang dengan hasil (88,3\%). Penelitian yang lain dari Purwati (2015:102) Model pembelajaran kooperatif teknik Bamboo Dancing lebih efektif dibandingkan metode diskusi dalam upaya peningkatan hasil belajar siswa pada mata pelajaran Pendidikan Kewarganegaran (PKn) di SMP N 5 Sleman. Hal ini dibuktikan dengan hasil uji Independent Sample $\mathrm{T}$ Test yang menunjukkan bahwa nilai $\mathrm{t}$ sebesar 5,078 dengan taraf signifikansi sebesar 0,000 atau sig $<0,05$. Hasil tersebut didukung oleh perolehan gain score pada kelas eksperimen menunjukkan nilai 0,505 sehingga dapat dikatakan memiliki kategori efektivitas sedang. Sedangkan, pada kelas kontrol yang tidakmenggunakan model pembelajaran kooperatif teknik Bamboo Dancing diperoleh nilai 0,066 sehingga dikatakan termasuk kategori rendah.

\section{METODE PENELITIAN}

Penelitian ini terdiri atas dua variabel yaitu variabel bebas dan variabel terikat, 
Variabel bebas pada penelitian ini adalah penerapan model pembelajaran kooperatif tipe bamboo dancing(X), sedangkan keterampilan berbicara sebagai variabel terikat (Y).Penelitian ini adalah penelitian Quasy Eksperimental. Dengan bentuk Nonequivalent Control Group design. Dalam penelitian ini melibatkan dua kelompok yaitu kelas eksperimen yang menggunakan model pembelajaran kooperatif tipebamboo dancingdan kelas kontrol menggunakan model pembelajaran konvensional dalam keterampilan berbicara bahasa Jerman siswa $\begin{array}{lllll}\text { kelas XI IPA } & \text { SMA Negeri } 7\end{array}$ Bulukumba.Model pembelajaran kooperatif tipe bamboo dancing dalam penelitian ini adalah pembelajaran yang berbasis kelompok. Melalui pembelajaran ini siswa mampu memahami materi yang diberikan, sedangkan keterampilan berbicara adalah kemampuan siswa dalam mengungkapkan ide, gagasan atau pikiran dalam menyampaikan informasi. Dalam hal ini datanya diperoleh melalui model tes berbicara dengan memerhatikan pelafalan dan tata bahasa yang digunakan. Materi yang digunakan dalam penelitian ini adalah Die Familie.Populasi dalam penelitian ini adalah seluruh siswa bahasa Jerman kelas XI IPA SMA Negeri 7 Bulukumba yang terdiri atas4 kelas, dengan jumlah siswa 102 orang.Sampel dalam penelitian menggunakan sampel acak (random sampling). Dari 4 kelas populasi dipilih dua kelas sebagai sampel. Dari hasil pemilihan secara acak terpilih kelas XI IPA I yang terdiri atas 24 siswa sebagai kelas eksperimen dan kelas XI IPA 3 yang terdiri atas 26 siswa sebagai kelas kontrol.
Teknik pengumpulan data dalam penelitian ini dilakukan dalam beberapa tahap sebagai berikut:

1. Pre-test, yaitu tes yang diberikan kepada siswa sebelum dilakukan perlakuan atau sebelum diajar dengan pembelajaran kooperatif tipe bamboo dancing yang bertujuan untuk mengetahui tingkat kemampuan awal siswa terhadap materi yang akan diajarkan yaitu perkenalan diri dan keluarga.

2. Post-test yaitu tes yang diberikan kepada siswa setelah diajar dengan pembelajaran kooperatif tipe bamboo dancing. Tes ini bertujuan untuk mengetahui sejauh mana tingkat pencapaian siswa setelah menerapkan model pembelajaran kooperatif tipebamboo dancingdengan memperkenalkan orang lain dan keluarganya.

Data yang diperoleh dianalisis dengan menggunakan analisis statistik deskriptif untuk menguji hipotesis dengan menggunakan uji-t. Namun sebelum dilakukan pengujian hipotesis terlebih dahulu dilakukan uji normalitas dengan menggunakan tabel-Z score dan chi kuadrat dan uji homogenitas dengan menggunakan uji $\mathrm{F}$ (Fisher), sebelum menentukan uji normalitas data dan homogenitas maupun uji hipotesis terlebih dahulu tentukan nilai ratarata (mean), simpangan baku dan varian.

\section{HASIL DAN PEMBAHASAN}

Pada bagian ini dibahas tentang hasil yang diperoleh dari analisis data penelitian tentang keefektifan model pembelajaran kooperatif tipe bamboo dancing dalam keterampilan berbicara bahasa Jerman siswa kelas XI IPA SMA Negeri 7 Bulukumba. Dalam penelitan ini, pembelajaran dilakukan 
selama 4 kali pertemuan setelah pemberianpre-test.Dalam pembelajaran tersebut, kedua kelas diajar dengan menggunakan metode yang berbeda. Pada kelas eksperimen siswa diajar menggunakan model pembelajaran tipe bamboo dancing untuk keterampilan berbicara, sedangkan kelas kontrol diajar menggunakan metode konvensional dengan buku Deutsch ist einfach.

Hasil pre-test menunjukkan bahwa nilai rata-rata (mean) keterampilan berbicara bahasa Jerman siswa kelas XI IPA 1 sebagai kelas eksperimen adalah 42 dengan nilai tertinggi adalah 58 dan nilai terendah adalah 25, sedangkan nilai rata-rata (mean) keterampilan berbicara bahasa Jerman siswa kelas XI IPA 3 sebagai kelas kontrol adalah 42,03 dengan nilai tertinggi 58 dan nilai terendah 25 . Uji normalitas pada data pretest kedua kelas menunjukan bahwa kelas eksperimen dan kontrol memiliki chi quadrat hitung masing-masing lebih kecil dari chi quadrat tabel. $\mathrm{X}^{2}{ }_{\text {hitung }}(-105,85)<\mathrm{X}_{\text {tabel }}{ }^{2}$ $(11,07)$ dan $X^{2}$ hitung $(-116,81)<X_{\text {tabel }}^{2}$ $(11,07)$, sehingga distribusi data pre-test dinyatakan normal.

Hasil post-testketerampilan berbicara siswa yang diajar dengan menggunakan model pembelajaran kooperatif tipebamboo dancing mengalami peningkatan. Hal ini dapat dilihat dari perolehan nilai untuk kelas eksperimen yaitu nilai terendah 50 dan nilai tertinggi 83 dengan perolehan rata-rata 66,25 . Sedangkan kelas kontrol yang belajar tanpa menggunakan model pembelajaran kooperatif tipebamboo dancing memperoleh nilai terendah 42 dan nilai tertinggi 75 dengan perolehan rata-rata 58,11.

Pada uji normalitas data post-test masing-masing kelas menunjukkan hal yang sama yaitu pada kelas eksperimen dan kelas kontrol nilai chi kuadrat hitung lebih kecil dari chi kuadrat tabel. $X^{2}$ hitung $(-110,78)<$ $\mathrm{X}_{\text {tabel }}^{2}(11,07)$ dan $\mathrm{X}^{2}$ hitung $(-118,6)<\mathrm{X}^{2}$ tabel $(11,07)$. Dengan demikian distribusi data kedua kelas tersebut dinyatakan normal. Setelah dilakukan uji normalitas dilanjutkan dengan pengujian homogenitas. Pengujian homogenitas bertujuan untuk mengetahui apakah data yang diperoleh bersifat homogen atau tidak. Berdasarkan hasil analisis data pre-test dan post-test kelas eksperimen dan kelas kontrol diketahui bahwa data tersebut bersifat homogen. Adapun hasil analisis data pre-test kedua kelas adalah $\mathrm{F}_{\text {hitung }}<\mathrm{F}_{\text {tabel }}$. $F_{\text {hitung }}=1,04<\mathrm{F}_{\text {tabel }}=5,050$. Sedangkan hasil analisis data post test adalah $\mathrm{F}_{\text {hitung }}<\mathrm{F}_{\text {tabel }}$. $\mathrm{F}_{\text {hitung }}=1,24<\mathrm{F}_{\text {tabel }}=5,050$.

Dari hasil analisis di atas, dilanjutkan dengan pengujian hipotesis dengan menggunakan uji-t. Uji-t dilakukan untuk melihat hasil akhir dari penelitian ini. Hasil dari nilai thitungdalam penelitian adalah 3,85

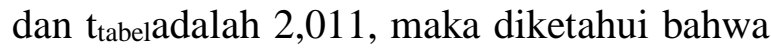
$t_{\text {hitung }}>t_{\text {tabel }}(3,85>2,011)$. Dengan demikian, $\mathrm{H}_{1}$ yang menyatakan bahwa model pembelajaran kooperatif tipe bamboo dancing efektif dalam keterampilan berbicara bahasa Jerman siswa diterima dan $\mathrm{H}_{0}$ yang menyatakan bahwa model pembelajaran kooperatif tipe bamboo dancing tidak efektif dalam keterampilan berbicara siswa ditolak. Sehingga dapat disimpulkan bahwa, $\mathrm{H}_{1}$ diterima maka penelitian tentang keefektifan model pembelajaran kooperatif tipe bamboo dancing dalam keterampilan berbicara bahasa Jerman siswa kelas XI IPA SMA Negeri 7 Bulukumba, dinyatakan berhasil. 


\section{KEEFEKTIFAN MODEL PEMBELAJARAN KOOPERATIF TIPE BAMBOO DANCING DALAM KETERAMPILAN BERBICARA BAHASA JERMAN SISWA KELAS XI IPA SMA NEGERI 7 BULUKUMBA}

KESIMPULAN

Penggunaan model pembelajaran kooperatif tipe bamboo dancing efektif dalam pembelajaran keterampilan berbicara bahasa Jerman siswa kelas XI IPA SMA Negeri 7 Bulukumba. Hal tersebut dibuktikan dari pengujian hipotesis menggunakan uji-t pada nilai post-test siswa dengan nilai analisis data yaitu $t_{\text {hitung }}=3,85$ $>t_{\text {tabel }}=2,011$ pada taraf signifikan 0,05 yang berarti bahwa setelah penggunaan model pembelajaran kooperatif tipe bamboo dancing dalam pembelajaran dimana $t_{\text {hitung }}$ lebih besar daripada $t_{\text {tabel }}$. Ini menunjukkan bahwa penggunaan model pembelajaran kooperatif tipe bamboo dancing efektif dalam pembelajaran keterampilan berbicara bahasa Jerman siswa kelas XI IPA SMA Negeri 7 Bulukumba.

\section{DAFTAR PUSTAKA}

Jufri, J. 2007. Metode Penelitian Bahasa. Sastra dan Budaya

Jufri, J., 2017. Strategi Pembelajaran Bahasa. Juwita. 2015. Keefektifan Media Puzzle Picture Dalam Keterampilan Berbicara Bahasa Jerman Siswa Kelas XI IPA SMAN 11 Makassar. Makassar: Skripsi FBS UNM.

Mantasiah, R., Juffri, J., \& Yusri, Y. 2017. Keefektifan Model Pembelajaran Jaring Laba-Laba (Webbed) dalam Keterampilan Menulis Karangan Sederhana Bahasa Jerman. INSANI, 20(2).

Purwati, Ari. 2015. Efektivitas Model Pembelajaran Kooperatif Teknik Bamboo Dancing Dalam Upaya Peningkatan Hasil Belajar Pkn
Siswa Smp N 5 Sleman

Yogyakarta.Yogyakarta:

SkripsiFakultas Ilmu Sosial UNY.

Qalbi, U. N., Mantasiah, R., Jufri, J., \& Yusri, Y. 2017. Efektivitas Model Pembelajaran Kooperatif Tipe Teams Games Tournaments dalam Keterampilan Menulis Bahasa Jerman Siswa Kelas XII IPA SMA Negeri 1 Bontonompo Kabupaten Gowa. INSANI, 20(1).

Romadloni, A., \& Mantasiah, R. Intercultural approach in foreign language learning to improve students' motivation. Senior Editors, 61.

Suprihatiningrum, Jamil. 2012. Strategi pembelajaran Teori \& Aplikasi. Yogyakarta: Ar-Ruzz Media.

Tahang, Hidayat. 2013. Penerapan Model Pembelajaran Kooperatif Tipe Coop Co-op dalam Meningkatkan Keterampilan Berbicara Bahasa Jerman Siswa Kelas XI IPA 1 SMA Negeri 1 Pinrang. Makassar : Skripsi FBS UNM.

Yunie, Y. 2014. Model Pembelajaran Dengan Pendekatan Psikoanalisis Melalui Metode Aversion Therapy \& Home Work. Bandung Barat: Alfabeta.

Yusri, Y., Mantasiah, R., \& Jufri, J. 2018. The Use Of Two Stay Two Stray Model in English Teaching to Increase Student's Learning Outcome. Journal of Advanced English Studies, 1(1), 39-43. 